\title{
The impact of migration on the competitiveness of the region and industry development
}

\author{
Stanislav Kotenko ${ }^{1}$, Hanna Shvindina ${ }^{2 *}$, and Iryna Heiets ${ }^{3}$ \\ ${ }^{1}$ Sumy State University, Oleg Balatskyi Department of Management, 2, Rymskogo-Korsakova St, \\ 40007 Sumy, Ukraine \\ ${ }^{2}$ Sumy State University, Oleg Balatskyi Department of Management, 2, Rymskogo-Korsakova St, \\ 40007 Sumy, Ukraine \\ ${ }^{3}$ School of Engineering, Department of Aerospace Engineering and Aviation, RMIT University, \\ Australia
}

\begin{abstract}
The impact of migration on Ukraine is multifaceted. It increases the threat of depopulation, leads to losing a part of the labour and intellectual potential, and thus, may become a factor inhibiting economic development. Today, there is a shortage of workers in almost all activities, especially in industry and construction. At the same time, according to scientists, in the absence of migration, unemployment in Ukraine would be $36.7 \%$ higher. Due to foreign earnings, the quality of life in migrant households is improving. Increasing consumer demand can contribute to the economic development of both individual regions and the country as a whole. This article aims to analyse the impact of migration processes on the regional competitiveness. Social, economic, and demographic factors should be taken into account when forming a comprehensive indicator of regional competitiveness. There is a need to evaluate the weight of individual factors and the mechanism of their impact on a comprehensive indicator of the regional competitiveness. Considering the findings of previous studies, the important role of industrial enterprises in assessing the level of regions' competitiveness is emphasized; it is necessary to study in more detail the relationship of migration processes and industrial potential of the region/country.
\end{abstract}

\section{Introduction}

The migration took place during the mankind's history, and recently, this phenomenon has been observed as multifaced, influencing negatively and positively economic development and development disparities. For Ukraine, the problem of migration was mitigated with good governance maintenance, and wealth increase became crucial. Ukrainians are one of the largest groups of migrants living and working in the EU [1], and the country has one of the biggest rates of depopulation among non-EU countries [2]. The economic process of labour

\footnotetext{
* Corresponding author: shvindina@management.sumdu.edu.ua
} 
force reallocation is linked to the innovation boosts, industrial development and living standards, and social security and guarantees for the future quality of life.

The previous finding of the multidimensional nature of competitiveness [3] proved that there is a link between productivity, high wages, and high standards of living which, after all, attract migrants.

In the works by Vasilieva T. and her colleagues [4-5], Didenko I. and her team [6-7], Lyeonov et al. [8], Smiianov S. et al. [9], Pudryk D. [10], the topic of labour migration is considered more widely. The authors focus on migration processes as those that have an impact not only on economic factors but also on the socio-cultural and medical spheres of society. The issue of employing migrant workers in the EU countries is explored in the works by Bardy R. and his co-authors [11], Zainea L. and a team [12], and Dave H. et al. [13-14]. Another aspect of research, namely the relationship between the EU representatives of government, and business, is presented in the works by Borella C. \& Rossinelli D. [15], Sysoyeva L. \& Kleinschmidt H. [16], and Kaya H. [17]. The papers [18-27] prove that social and financial security, and self-development are the core determinants for the human capital development. The scientists in the papers [28-42] confirm the impact of environmental determinants on the region's competitiveness, social and economic development. Besides, the papers [43-110] prove that innovation development influences human capital.

The current research aims to find a missing link among the global competitiveness, the competitiveness of the region, and labour migration; and to analyse the impact of migration processes on the regional competitiveness.

\section{Materials and Methods}

This research is structured in two parts; firstly, the bibliometric analysis is accomplished using the VOSviewer software to visualize the results. The source of the data is Scopus database, and the selection parameters are keywords. As the result, 65 documents were revealed for a combination of keywords "competitiveness" and "labour migration", and there were analysed 115 documents that have "region competitiveness" among the keywords.

The second part is content analysis of the recent findings on the global competitiveness index (GCI), productivity dynamics of the regions of Ukraine, and labour migration trends. The data sources are open databases of Ukrainian Statistic Service, World Bank reports, GCI reports.

Finally, the limitations and directions for further research of the missing link between competitiveness and labour migration are provided in the last section.

\section{Results and discussions}

\subsection{Literature review and bibliometric analysis}

The literature review is aimed to identify the interlinks between the main terms as markers of core academic research, and knowledge gaps which could be helpful for further studies. Using bibliometric analysis, the authors analysed publications on the related topics in the Scopus database, and formed a visualization of key concepts and terms, their relationship with each other. Figure 1 shows a visualization map which is based on 65 documents with the keywords "competitiveness" and "labour migration" (items - 32, clusters - 4, links - 348). 


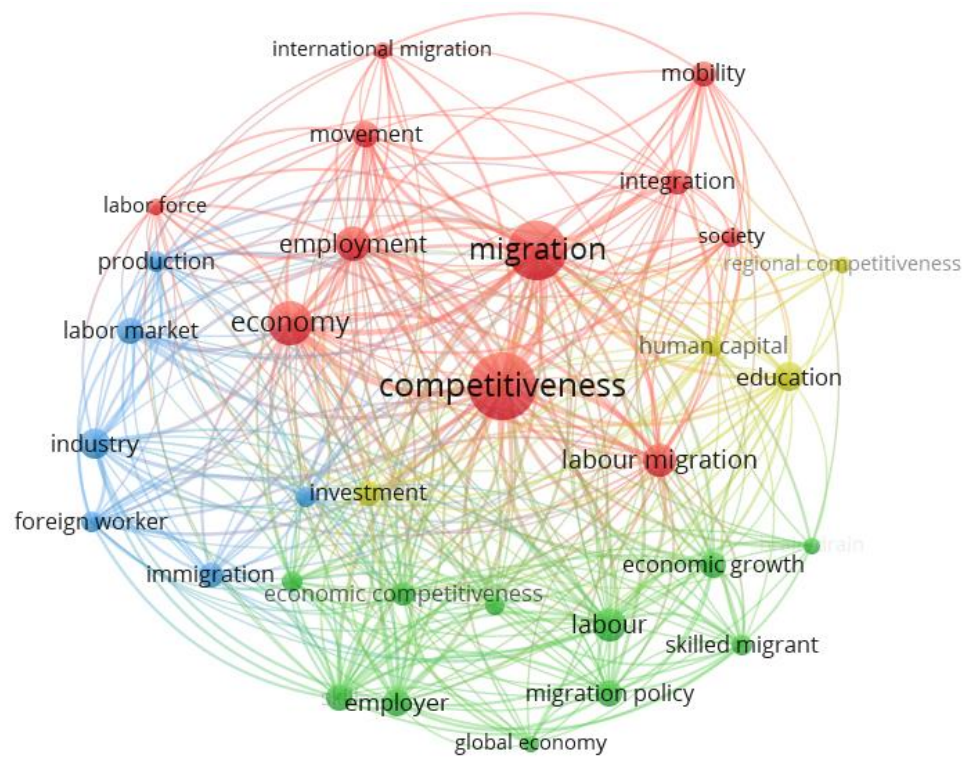

Fig. 1. A visualization map by keywords "competitiveness" and "labour migration" (developed by the authors using the VOSviewer application).

This visualization of key concepts allows the researchers to understand and see how labour migration can be linked to competitiveness. In fig. 1, the economic competitiveness is directly related to the "brain drain" phenomenon, skilled migrants, and economic growth. In addition, it should be noted that regional competitiveness is related to the level of investment, education, and quality of human capital in the region.

Based on the results of the above visualization, it can be concluded that labour migration is strongly related to the competitiveness of both countries and individual regions. The influx of migrant professional workers can significantly change labour market trends and stimulate economic growth. The paper "The labour market characteristics and labour market impacts of immigrants in Ireland" [111] confirmed it. The researchers conducted a study of the immigrant's labour market in Ireland. The analysis resulted in the assessment of the immigration impact on the Irish labour market. The authors find out that immigrants are a highly educated group, but not all of them work in their professional field, which fully reflects the real level of their education (which can be also true about the migrant labour markets of the other EU countries). One of the significant findings of this publication is the fact that more highly skilled migrants working in the profession stimulate the growth of the country's competitiveness, increase GDP and create real competition in the domestic labour market. In the case of low-skilled labour, the economic effect is reverse.

In the work "Scientific Mobility, Career Progression, and Excellence in the European Research Area" [112] (93 citations), the author focuses on labour migration in the research and scientific environment, raises the issue of coordinating the migration policy in the field of scientific exchange to increase the competitiveness of scientific personnel in the EU countries.

The paper "The Economic Geography of Labour Migration: Competition, Competitiveness and Development" by Kancs D [113] (22 citations) presented the findings on labour migration in the enlarged EU. The author considers the determinants of labour migration, such as market potential, wages, costs of living, on the one hand, and labour migration, on the other hand. Although migrant workers are attracted to the market potential 
of the EU countries, they also affect this market potential and the competitiveness of the country/region.

Returning to the concept of "region competitiveness", a new visualization map was formed. Using the VOSviewer tool, there were analysed 115 documents which are included in the Scopus database by keywords "region competitiveness" (items - 30, clusters - 5, links - 366). The obtained visualization can be seen in Fig.2.

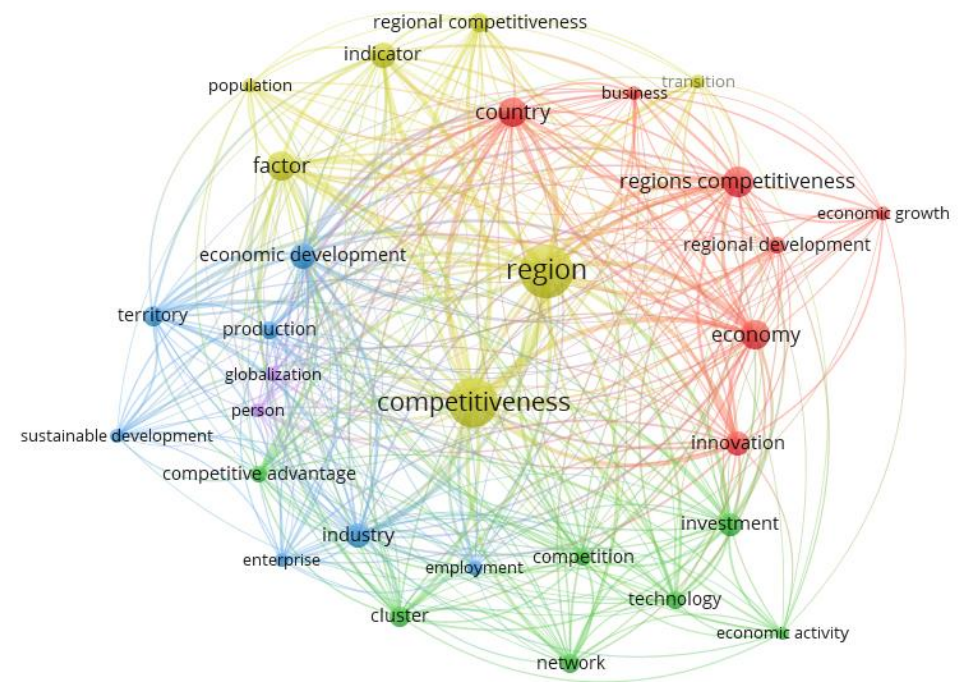

Fig. 2. A visualization map by keywords "region competitiveness" (developed by the authors using VOSviewer application).

In the mentioned sample, the most cited article (210 citations) is "Cities, Regions and Competitiveness" [114], where the author considers the position of regional firms in international markets as a factor in the competitiveness of a region or an individual city. Among the factors of regional competitiveness, Turok I. also refers to the efficiency of local resources. The author notes that it is possible to focus on the advantages of scale and economic diversity in some regions to increase competitiveness. Such advantages may arise due to the formation of economic and industrial zones within the country.

The team of researchers from Poland in their work "Regional Competitiveness in Poland: Creating an Index" [115] examines the regions' competitiveness of Poland, based on the regional competitiveness index of Robert Huggins [116]. The authors of the article, taking into account the disparities in different indicators of Polish regions, proposed using the Huggins method [116]. This study presents a methodology of three-level types of formation indicators (inputs, outputs, and outcomes), which includes business density, knowledgebased business, economic participation (inputs), productivity (outputs), unemployment rate and earnings (outcomes).

The analysis in more detail of the works by Huggins R. [117-119] reveals that regional competitiveness is considered an important source of economic development in a globalized economy. Huggins maintains that the competitiveness of the region refers to the existence of conditions that allow firms to compete in their chosen markets within a particular region, according to Porter M. [120]. Back in 1997, Storper M. [121] proved that the region's/country's competitiveness is the ability to attract and retain companies with a stable or growing market share in their activities while maintaining a relatively high standard of living of those involved (employees and management). It means that the region's competitiveness can vary significantly according to its geographical location, as regions develop at different rates depending on a large number of factors. 


\subsection{A comparative study of regions' development and labour migration dynamics}

Migration processes play an important role in the life of the Ukrainian society. Thus, modern migration implements the function of accelerating human development, because it contributes to the expansion of the individual's worldview, affects the socio-psychological characteristics of the individual, activates the internal human resources for social activity. Migration performs a redistributive function, as it is reflected in the dynamics and nature of demographic processes, in expanding or, conversely, narrowing the mode of demographic reproduction by changing the gender and age structure of the inhabitants of the territory, in the accumulation of labour resources. Migration also has a selective function: not all categories of the population are equally prone to displacement. That means that migration has the potential for qualitative changes in the composition and structure of the economically active (and inactive) population [122].

The development of modern migration processes in Ukraine is influenced by several important factors, including the annexation of the Crimea and the conflict in eastern Ukraine and the resulting economic crisis; initiating important reforms, which, however, proved to be insufficiently decisive and consistent; promotion through European and Euro-Atlantic integration, in particular, the acquisition of a visa-free regime with the EU in June 2017; migration experience and extensive migration networks formed as a result of many years of active participation of the Ukrainians in labour migration abroad [123].

Due to some improvement in the economic situation in 2016-2018 and the adaptation of society to the crisis, the volume of external migration of Ukrainians has been stabilized but remains significant. At the same time, the attractiveness of the country as a host for immigrants is low. The unfavourable demographic trends, the outflow of the population may become a brake on economic development. The welfare lag of Ukraine as compared to the neighbouring countries will continue in the medium term. Thus, external migration will continue, and under the war conflict in the east of the country and destabilization of the internal situation, migration may even increase [123].

The impact of labour migration on the Ukrainian economy can be assessed by determining the share of GDP generated by immigrants and emigrants.

Immigrant workers are mainly managers engaged in trade and repair, industry, information, and telecommunications. In 2018, the State Employment Service, which issues work permits for foreigners, registered 16,000 foreign workers (Fig. 3). In 2018, the most numerous among them were citizens of Turkey (about 3 thousand), the Russian Federation (1.6 thousand), China, and Belarus (about 1 thousand equally).

In turn, the number of labour migrants who are currently officially employed in the EU is growing. According to Eurostat, the number of permits valid at the end of the year for Ukrainian citizens to stay in the EU-28 has doubled over the last decade and amounted to about 1.2 million in 2018 (Fig. 4).

Most Ukrainians lived in Poland (442 thousand), Italy (234 thousand), the Czech Republic (132 thousand), Germany (121 thousand), and Spain (92 thousand). According to the National Bank of Ukraine, which calculates the volume of private transfers when calculating the country's balance of payments, they grew steadily and in 2018 reached $\$ 11.1$ billion (US dollars), which corresponds to $8.5 \%$ of the Ukrainian GDP. The amount of transfers more than quadrupled the amount of foreign direct investment. The main country of remittances origin was Poland: in 2018 Ukraine received $32.8 \%$ of all remittances (\$3.6 billion, US dollars). Compared to 2017, the volume of remittances from the Czech Republic almost doubled (7.6\% of all remittances, or \$846 million USD). 


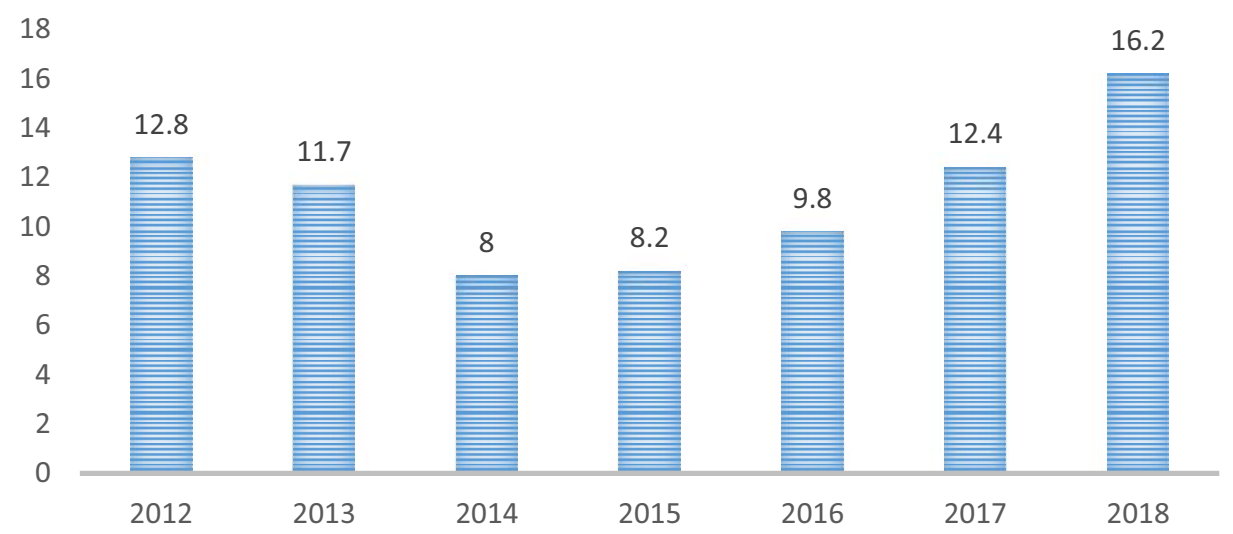

Fig. 3. The number of foreigners who temporarily worked in Ukraine with an employment permit, at the end of the year, thousand people [123].

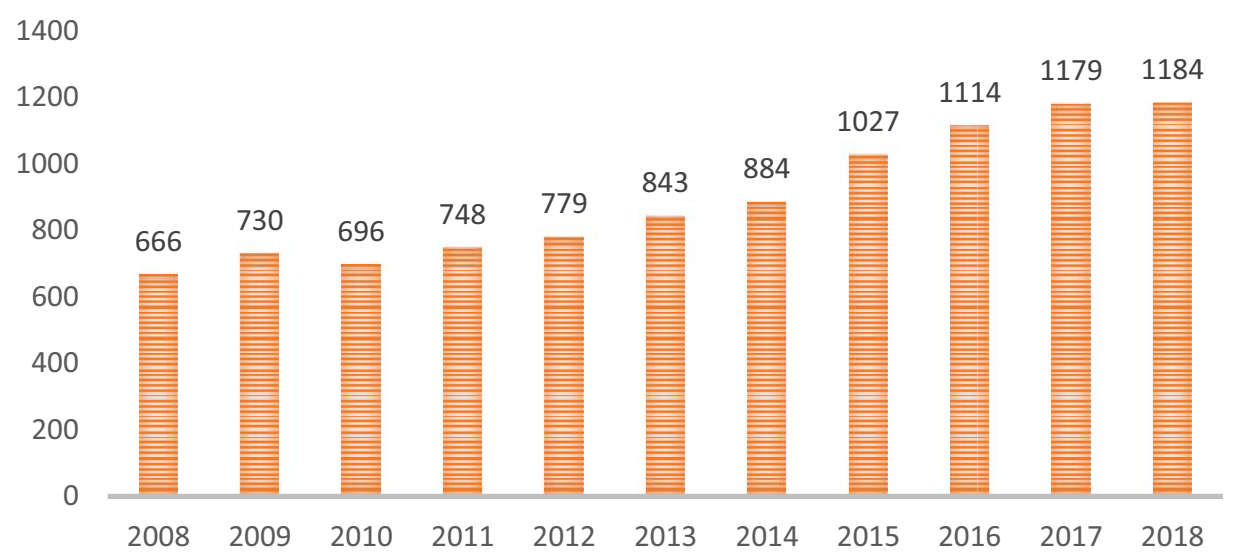

Fig. 4. The number of valid at the end of the year residence permits of the Ukrainian citizens in the EU, thousand people [124].

Following the numbers allows concluding that Ukraine is a supplier of the labour force to the neighbouring EU member states. External emigration is a significant part of economic development, i.e., remittances coming to Ukraine from abroad increase the purchasing power of the population and saturate the budget.

Linking the region's competitiveness to the migration factors may be done through Paul Krugman's theory [125]. Krugman suggested that the region's competitiveness is based on its ability to provide a relatively attractive level of wages and/or employment prospects for young people. Krugman believes that it is important for the regional competitiveness to maintain a high standard of living because this factor is the ultimate goal of competitive activity. P. Krugman introduced the theory, which was later developed by the scholars Barrett, Bergin, and Duffy [45]. It outlined the benefits of the migration policies of developing countries, which instead of "supplying" migrants, began to invite skilled labour from abroad. In the scientific literature, the case of the economic development of Ireland (the "Celtic Tiger") is equated with the "Asian Tigers" - the economic growth in Asian countries.

Returning to the Ukrainian regional migration, the study on migration growth / population decline in the regions of Ukraine (except for the occupied Crimea, Donetsk and Luhansk 
regions) is needed to be conducted in detail. Table 1 shows the official statistics on interregional migration for 2014-2019, presented in fragments to demonstrate the unfavourable trends.

Table 1. Migration increase/decrease by regions for 2014-2019 (number of persons) (excluding Donetsk, Luhansk regions, and the Autonomous Republic of Crimea) [126, fragmented].

\begin{tabular}{|c|c|c|c|c|c|c|}
\hline No & Region & $\mathbf{2 0 1 9}$ & $\mathbf{2 0 1 8}$ & $\mathbf{2 0 1 7}$ & $\mathbf{2 0 1 6}$ & $\mathbf{2 0 1 5}$ \\
\hline 1 & Kyiv & 27343 & 27142 & 30677 & 11402 & 11225 \\
\hline 2 & Odessa & 9075 & 7696 & 4725 & 3380 & 986 \\
\hline 3 & Kharkiv & 5436 & 4534 & 12069 & 797 & 4981 \\
\hline 4 & Lviv & 1099 & 1886 & 2666 & 4982 & 1335 \\
\hline 5 & Poltava & 411 & 76 & -655 & -159 & 990 \\
\hline$\ldots$ & $\ldots$ & $\ldots$ & $\ldots$ & $\ldots$ & $\ldots$ & $\ldots$ \\
\hline 18 & Zaporizhzhia & -2155 & -2172 & -2714 & -1689 & -797 \\
\hline 19 & Sumy & -2250 & -2103 & -731 & 1152 & -974 \\
\hline 20 & Rivne & -2474 & -2198 & -1827 & -253 & -782 \\
\hline 21 & Vinnytsia & -2724 & -3842 & -4625 & -2505 & 686 \\
\hline 22 & Kirovograd & -3345 & -2294 & -1657 & 24 & -688 \\
\hline
\end{tabular}

According to Table 1, the positive migration takes place only in regions whose centres are cities with a population of over a million people. Typically, these are the regions with developed infrastructure and many industrial enterprises where the migration growth is noticeable, which is due to higher average wages (Table 2).

Table 2. Average wages by regions of Ukraine for 2016-2020 (UAH) (excluding Donetsk, Luhansk regions, and the Autonomous Republic of Crimea) [126, fragmented].

\begin{tabular}{|c|c|c|c|c|c|c|}
\hline No & Region & $\mathbf{2 0 2 0}$ & $\mathbf{2 0 1 9}$ & $\mathbf{2 0 1 8}$ & $\mathbf{2 0 1 7}$ & $\mathbf{2 0 1 6}$ \\
\hline 1 & Kyiv & 11886.9 & 11010 & 9093 & 7187 & 5253 \\
\hline 2 & Dnipropetrovsk & 11686.0 & 10759 & 8865 & 6939 & 5084 \\
\hline 3 & Zaporizhzhia & 11565.1 & 10484 & 8729 & 6863 & 5098 \\
\hline 4 & Mykolaiv & 11425.7 & 9981 & 8166 & 6711 & 4892 \\
\hline 5 & Poltava & 10823.5 & 9852 & 8378 & 6547 & 4626 \\
\hline 6 & Odessa & 10341.4 & 9252 & 8013 & 6541 & 4825 \\
\hline 7 & Lviv & 10306.8 & 9276 & 8003 & 6392 & 4574 \\
\hline$\ldots$ & $\ldots$ & $\ldots$ & $\ldots$ & $\ldots$ & $\ldots$ & $\ldots$ \\
\hline 18 & Ternopil & 9384.5 & 8280 & 6971 & 5552 & 3731 \\
\hline 19 & Kherson & 9359.4 & 8192 & 7060 & 5838 & 4026 \\
\hline 20 & Chernihiv & 9336.0 & 8212 & 6995 & 5636 & 4008 \\
\hline 21 & Volyn & 9268.4 & 8680 & 7337 & 5843 & 4052 \\
\hline 22 & Chernivtsi & 9155.9 & 8074 & 6990 & 5621 & 3846 \\
\hline
\end{tabular}

The Table 2 presents the disproportions in wages; it is observed that the average annual wages in different regions of Ukraine are quite different and may differ by almost 3000 $\mathrm{UAH} / \mathrm{month}$. The leading regions with a high level of wages can also include Zaporizhzhia 
and Mykolaiv regions, which reflected the migration reduction by region in Table 1 . This paradox can be explained by the closeness of the occupied territories and the environmental protection zone (Crimea and Donetsk region), the closeness of the armed forces of Russian Federation, and the war conflict zone. Under such conditions, there is a natural outflow of the working population to other regions/countries to keep the safety of life, resulting in an increase in the number of vacancies in the region and the average wage, which is associated with labour deficit.

The region competitiveness in the context of human development and migration processes (a case of Khmelnitsky region) was considered by Kuriy L. [127]. The author uses an existing tool - the Global Competitiveness Index (GCI) for the regions of Ukraine, which includes 12 components. Each of these components consists of a set of indicators, which in turn consist of statistics and data obtained by interviewing company executives. According to this methodology, the calculation of the GCI twelve components of competitiveness is divided into three separate sub-indices ("basic requirements", "efficiency tools" and "factors of innovation and development"), which affect the level of the region's competitiveness according to its stage of development. The components of the regions GCI [128] can be represented as follows:

1. Quality of institutions (public and private institutions).

2. Infrastructure.

3. Macroeconomic stability.

4. Health and primary education.

5. Higher education and training.

6 . The efficiency of the market of goods and services.

7. Labour market efficiency.

8. Development of the financial market.

9. The level of technological development.

10. The size of the domestic market.

11. Competitiveness of companies (level of business development).

12. Innovative potential [128].

As can be seen from the components of the GCI regions, migration processes directly affect regional competitiveness due to the strong relationship with the labour market and its efficiency. Also, the competitiveness of the region is determined by the development of human potential, which in quantitative and qualitative terms depends on migratory inflows and outflows. Increasing competitiveness indicators stimulate migratory attractiveness, which leads to the influx of migrants as carriers of the human potential. The accumulation of the human potential and its realization, in turn, contributes to the growth of competitiveness.

It should be noted that a particular position in the complex indicators of regions GCI belongs to the competitiveness of companies or the level of business development. In current study, only industrial enterprises were taken into account because they form a large share $(25 \%)$ of Ukraine's GDP, at the level of wholesale and retail trade (24\%) [129].

To confirm the opinion about the relationship between the migration factor and the competitiveness of industrial enterprises, statistics on the volume of industrial products sold by regions of Ukraine is presented (Table 3).

As can be seen from Table 3, the TOP-5 regions in terms of sales of industrial products almost completely coincide with Tables 1, 2 (4 regions out of 5). This fact confirms the idea of the relationship between the migration factor and the competitiveness of industrial enterprises and emphasizes the significant contribution of industry in forming the average wage in the regions. 
Table 3. Industrial production sold by a region, million dollars without VAT/Mln.USD, excluding VAT and excise (excluding Donetsk, Luhansk regions, and the Autonomous Republic of Crimea)

[130, fragmented].

\begin{tabular}{|c|c|c|c|c|c|c|}
\hline \multirow{2}{*}{ No } & \multirow{2}{*}{ Region } & \multicolumn{5}{|c|}{ Year/dollar exchange rate in the respective year } \\
\cline { 3 - 7 } & $2019 / 25.8$ & $2018 / 27.2$ & $2017 / 26.6$ & $2016 / 25.6$ & $2015 / 21.84$ \\
\hline 1 & Dnipropetrovsk & 17601.71 & 17701.52 & 15710.68 & 12670.61 & 13239.12 \\
\hline 2 & Zaporizhzhia & 7561.21 & 7766.11 & 7061.01 & 5595.79 & 5987.11 \\
\hline 3 & Kharkiv & 7195.32 & 6998.46 & 6263.50 & 5108.25 & 4675.62 \\
\hline 4 & Poltava & 6532.19 & 6866.16 & 5974.72 & 4920.25 & 4730.00 \\
\hline 5 & Kyiv & 4681.00 & 4202.11 & 3545.83 & 3226.41 & 3143.37 \\
\hline 6 & Lviv & 4080.88 & 3684.89 & 3078.62 & 2632.35 & 2470.49 \\
\hline$\ldots$ & $\ldots$ & $\ldots$ & $\ldots$ & $\ldots$ & $\ldots$ & $\ldots$ \\
\hline 20 & Zakarpattia & 928.62 & 877.28 & 782.56 & 686.13 & 636.22 \\
\hline 21 & Ternopil & 804.52 & 801.16 & 732.33 & 614.82 & 541.52 \\
\hline 22 & Chernivtsi & 528.26 & 569.09 & 392.27 & 337.31 & 308.72 \\
\hline
\end{tabular}

Table 4. TOP-5 regions of Ukraine according to the indicators listed in tables 1-3 (for 2019) (excluding Donetsk, Luhansk regions, and the Autonomous Republic of Crimea) [ranked by authors, using 126].

\begin{tabular}{|l|l|l|}
\hline Migration growth & \multicolumn{1}{|c|}{ Average salary } & Sold Industrial Products \\
\hline 1. Kyiv & 1. Kyiv & 1. Dnipropetrovsk \\
\hline 2. Odessa & 2. Dnipropetrovsk & 2. Zaporizhzhia \\
\hline 3. Kharkiv & 3. Zaporizhzhia & 3. Kharkiv \\
\hline 4. Lviv & 4. Mykolaiv & 4. Poltava \\
\hline 5. Poltava & 5. Poltava & 5. Kyiv \\
\hline
\end{tabular}

The issue of migration, countries' and regions' competitiveness can also be considered in terms of potential economic growth. This topic was researched by Gromenkova S. [131], in whose paper migration was associated with significant risks and opportunities for development. Migration leads to the loss of the population of the most active age, which has a high level of education, reduces the birth rate, accelerates the aging of the population. At the same time, according to the research based on economic and mathematical modelling, without transactions from abroad from migrants to their families and dependants, Ukraine would lose $7.1 \%$ of its economic potential. Consumption would decrease by $18 \%$, and household income - by $14-21 \%$.

As the main economic factor of labour migration, remittances can have different effects on the national economy of the donor country, the competitiveness of its regions, and entire industries. Remittances from migrants, which will be used for investment purposes, have a great potential for a positive impact on the national economy and economic growth. At the state level, by improving tax laws and reducing tax barriers to financial intermediation, it is possible to direct the cash flows of migrant remittances to invest in the industry, trade, or tourism.

Migrant workers prefer to invest money in their home communities, so it will be advisable to create all the conditions at the local level to promote targeted investment in those areas that need to be "pulled up" by the regions to increase the comprehensive indicator of the GCI. 
It will be a significant advantage for migrant workers to return home and work in enterprises where the migrants themselves are shareholders. In this way, they can receive additional dividends, participate in the direct development of local business, become an "economic donor" and take care of their future and the future of their children in their homeland.

\section{Discussion and conclusion}

The analysis of interdependence among the region competitiveness indicators, industrial enterprises and migration processes allows defining the basic directions of overcoming the negative tendencies and strengthening positive preconditions of GCI indicator growth:

- the main factors that reduce the competitiveness of the region in the industry are low production, shortage of scientific and engineering personnel, low innovation, and instability of the state policy in the field of industrial production;

- when determining the indicator of industrial enterprises' competitiveness as a part of the region's GCI, it is necessary to take into account the business environment of a particular region, the innovative activity of the analysed enterprises, and their direct impact on the local labour market;

- the state migration policy should be aimed at retaining young professionals in Ukraine, working simultaneously with the existing base of migrant workers on their return home;

- infrastructure development and creation of branch clusters (industrial, innovative, scientific) will allow balancing internal migration, decentralizing influence of cities with a population of millions;

- improving the situation (at the state level) with natural population decline and migration outflow, which is a consequence of low living standards and population incomes of certain regions;

- creating conditions for increasing the indicators of the region's attractiveness for migration will overcome the demographic crisis due to the influx of migrants.

Issues of labour migration are quite complex during the global pandemic and hostilities in eastern Ukraine. Migration affects all spheres of public life; almost every family has its migrant workers abroad. Even more, migrant workers travel to work in large Ukrainian cities and regions where the average wage is higher than in their home community. Therefore, one of the biggest problems that need to be solved in terms of regional competitiveness and industrial development is to stop the outflow of specialists to other cities/countries, creating the best conditions for their work at home.

Acknowledgments: This research was funded by the grant from the Ministry of Education and Science of Ukraine «Reforming the lifelong learning system in Ukraine for the prevention of the labour emigration: a coopetition model of institutional partnership» (No 0120U102001).

\section{References}

1. O. Fedyuk, M. Kindler, In Ukrainian Migration to the European Union, 1-14 (2016). Springer, Cham. URL: https://doi.org/10.1007/978-3-319-41776-9_1

2. H. Shvindina, Forum Scientiae Oeconomia, 4 (1), 5-19 (2016). URL: http://ojs.wsb.edu.pl/index.php/fso/article/view/230/175

3. H. Shvindina H. In Responsible Consumption and Production. Encyclopedia of the UN Sustainable Development Goals. Springer, Cham. (2020). URL: https://doi.org/10.1007/978-3-319-95726-5_63

4. T. Vasilyeva, O. Kuzmenko, V. Bozhenko, O. Kolotilina, CEUR Workshop Proceedings, 2422, 134-146 (2019). 
5. T. Vasilyeva, S. Bilan, K. Bagmet, R. Seliga, Economics and Sociology, 13(1), 271294 (2020). doi:10.14254/2071-789X.2020/13-1/17

6. I. Didenko, K. Volik, T. Vasylieva, S. Lyeonov, N. Antoniuk, E3S Web of Conferences, 202 (2020). doi:10.1051/e3sconf/202020203028

7. I. Didenko, K. Volik, T. Vasylieva, S. Lyeonov, N. Antoniuk, E3S Web of Conferences, 234 (2021). doi:10.1051/e3sconf/202123400010

8. S. Lyeonov, T. Vasilyeva, Y. Bilan, K. Bagmet, International Journal of Trade and Global Markets, 14(3), 272-291 (2021). doi:10.1504/IJTGM.2021.115712

9. V. A. Smiianov, T.A. Vasilyeva, O. Y. Chygryn, P. M. Rubanov, T. M. Mayboroda, Wiadomosci Lekarskie, 73(10), 2181-2187 (2020).

10. D. Pudryk, SocioEconomic Challenges, 5(1), 133-143 (2021). https://doi.org/10.21272/sec.5(1).133-143.2021

11. R. Bardy, A. Rubens, P. Eberle, Business Ethics and Leadership, 1(4), 5-21 (2017). DOI: $10.21272 /$ bel.1(4).5-21.2017

12. L.N. Zainea, S.G. Toma, P. Marinescu, A. Chițimiea, Business Ethics and Leadership, 4(4), 85-98 (2020). https://doi.org/10.21272/bel.4(4).85-98.2020

13. H. Dave, Financial Markets, Institutions and Risks, 2(4), 39-56 (2018). DOI: http://doi.org/10.21272/fmir.2(4).39-56.2018

14. H. Dave, Financial Markets, Institutions and Risks, 2(3), 87-103 (2018). DOI: 10.21272/fmir.2(3).87-103.2018

15. C.A. Borella, D. Rossinelli, SocioEconomic Challenges, 1(4), 59-72 (2017). DOI: 10.21272sec.1(4).59-72.2017

16. L. Sysoyeva, H. Kleinschmidt, SocioEconomic Challenges, 1(1), 48-53 (2017). http://doi.org/10.21272/sec.2017.1-05.

17. H. D. Kaya, Financial Markets, Institutions and Risks, 4(3), 13-23 (2020). https://doi.org/10.21272/fmir.4(3).13-23.2020

18. Y. Kharazishvili, A. Kwilinski, O. Grishnova, H. Dzwigol, Sustainability, 12(21), 8953 (2020)

19. M. Bublyk, V. Koval, O. Redkva, Marketing and Management of Innovations, 4, 229240. (2017). https://doi.org/10.21272/mmi.2017.4-20

20. H. Dzwigol, Academy of Strategic Management Journal, 19(4), 1-8 (2020)

21. A. Kwilinski, O. Vyshnevskyi, H. Dzwigol, Journal of Risk and Financial Management, 13(7), 142 (2020)

22. M. M. Sulphey, M. Naushad, Marketing and Management of Innovations, 4, 11-21. (2019). http://doi.org/10.21272/mmi.2019.4-01

23. A. Kwilinski, H. Dzwigol, V. Dementyev, International Journal of Entrepreneurship, 24(1 Special Issue), 1-5 (2020)

24. L. Melnyk, L. Sineviciene, O. Lyulyov, T. Pimonenko, I. Dehtyarova. Problems and Perspectives in Management, 16(1), 105-114. (2018). doi:10.21511/ppm.16(1).2018.10

25. A. Sokolovska, T. Zatonatska, A. Stavytskyy, O. Lyulyov, V. Giedraitis. Research in World Economy, 11(4), 1-15. (2020). doi:10.5430/rwe.v11n4p1

26. M. Kordos, Marketing and Management of Innovations, 3, 341-353. (2019) http://doi.org/10.21272/mmi.2019.3-26

27. H. Dzwigol, M. Dzwigol-Barosz, R. Miskiewicz, A. Kwilinski, Entrepreneurship and Sustainability Issues, 7(4), 2630-2644 (2020) 
28. N. Letunovska, O. Lyuolyov, T. Pimonenko, V. Aleksandrov. Paper presented at the E3S Web of Conferences, , 234 doi:10.1051/e3sconf/202123400008.

29. A. Teletov, S. Teletova, N. Letunovska. Periodicals of Engineering and Natural Sciences, 7(2), 458-465 (2019).

30. N. Letunovska, L. Saher, T. Vasylieva, S. Lieonov. Paper presented at the E3S Web of Conferences, 250 (2021).

31. L. Saher, L. Syhyda, O. Korobets, T. Berezianko. Paper presented at the E3S Web of Conferences, , 234 doi:10.1051/e3sconf/202123400011

32. I. Vakulenko, L. Saher, L. Syhyda, S. Kolosok, A. Yevdokymova. Paper presented at the E3S Web of Conferences, , 234 doi:10.1051/e3sconf/202123400020

33. A. Bondarenko, L. Zakharkina, L. Syhyda, L. Saher. International Journal of Sustainable Development and Planning, 15(4), 439-449 (2020). doi:10.18280/ijsdp.150404

34. A. Rosokhata, O. Rybina, A. Derykolenko, V. Makerska. Research in World Economy, 11 (4), 42-52 (2020).

35. A. Rosokhata, M. Minchenko, L. Khomenko, O. Chygryn. Paper presented at the E3S Web of Conferences, 250 (2021) doi:10.1051/e3sconf/202125003002

36. O. Lyulyov, T. Pimonenko, A. Kwilinski, H. Dzwigol, M. Dzwigol-Barosz, V. Pavlyk, P. Barosz, Energies, 14(2), 373 (2021)

37. M. Soliman, O. Lyulyov, H. Shvindina, R. Figueiredo, T. Pimonenko, European Journal of Tourism Research, 28, (2021)

38. T. Pimonenko, O. Prokopenko, J. Dado, International Journal of Ecological Economics and Statistics, 38(4), 46-57. (2017)

39. O. Lyulyov, Y. Chortok, T. Pimonenko, O. Borovik, International Journal of Ecology and Development, 30(3), 1-10. (2015)

40. O. Prokopenko, J. Cebula, S. Chayen, T. Pimonenko, International Journal of Ecology and Development, 32(1), 98-107. (2017)

41. J. Cebula, T. Pimonenko. International Journal of Ecology and Development, 30(2), 20-30. (2015)

42. O. Chygryn, A. Rosokhata, O. Rybina, N. \& Stoyanets. Paper presented at the E3S Web of Conferences, , 234 (2021). doi:10.1051/e3sconf/202123400004

43. P. Gallo, B. Mihalcova, O. Vegsoova, T. Dzurov-Vargova, N. Busova, Marketing and Management of Innovations, 2, 11-20. (2019). http://doi.org/10.21272/mmi.2019.2-01

44. E. Mazur-Wierzbicka, Marketing and Management of Innovations, 1, 335-356. (2019) http://doi.org/10.21272/mmi.2019.1-28

45. S. Cyfert, A. Chwiłkowska-Kubala, W. Szumowski, R. Miśkiewicz, PLoS ONE, 16(4), e0249724 (2021)

46. B. Czyżewski, A. Matuszczak, R. Miskiewicz, Technological and Economic Development of Economy, 25(1), 82-102 (2019)

47. H. Dzwigol, M. Dzwigol-Barosz, Z. Zhyvko, R. Miskiewicz, H. Pushak, Journal of Security and Sustainability Issues, 8(3), 307-317 (2019)

48. E. Gross-Golacka, M. Kusterka-Jefmanska, R. Miskiewicz, B. Jefmanski, A. Rzepka, T. Kupczyk, European Research Studies Journal, XXIV(2B), 410-429 (2021)

49. L. Hrytsenko, I. Boiarko, O. Tverezovska, J. Polcyn, R. Miskiewicz, Marketing and Management of Innovations, 2, 155-165 (2021)

50. R. Miskiewicz, Polityka Energetyczna, 21(2), 49-62 (2018) 
51. R. Miskiewicz, Virtual Economics, 2(2), 37-47 (2019)

52. R. Miskiewicz, Marketing and Management of Innovations, 3, 371-381 (2020)

53. R. Miskiewicz, Energies, 13(22), 6106 (2020)

54. R. Miśkiewicz, Journal of Risk and Financial Management, 14(2), 59 (2021)

55. R. Miśkiewicz, R. Wolniak, Sustainability, 12(14), 5776 (2020)

56. K. Pająk, O. Kvilinskyi, O. Fasiecka, R. Miskiewicz, Economics and Environment, 2(61), 122-138, (2017)

57. O. Prokopenko, R. Miskiewicz, Entrepreneurship and Sustainability Issues, 8(2), 269284 (2020)

58. A. Rzepka, R. Borowiecki, R. Miskiewicz, Z. Olesinski, European Research Studies Journal, XXIV(2), 1149-1162 (2021)

59. P.W. Saługa, K. Szczepańska-Woszczyna, R. Miśkiewicz, M. Chłąd, Energies, 13(18), 4833 (2020)

60. H. Dźwigoł, Virtual Economics, 4(1), 98-117 (2021)

61. H. Dzwigol, Marketing and Management of Innovations, 1, 128-135 (2020)

62. H. Dzwigol, Marketing and Management of Innovation, 1, 324-335 (2021)

63. H. Dzwigol, R. Wolniak, Przemysl Chemiczny, 97(7), 1114-1116 (2018)

64. H. Dzwigol, M. Dzwigol-Barosz, Academy of Strategic Management Journal, 19(5), 17 (2020)

65. H. Dzwigol, S. Shcherbak, M. Semikina, O. Vinichenko, V. Vasiuta, Academy of Strategic Management Journal, 18(SI1), 1-8 (2019)

66. H. Dzwigol, O. Aleinikova, Y. Umanska, N. Shmygol, Y. Pushak, Journal of Entrepreneurship Education, 22(1S), 1-7 (2019)

67. H. Dzwigol, M. Dźwigoł-Barosz, A. Kwilinski, International Journal of Entrepreneurship, 24(1), 1-5 (2020)

68. Y. Kharazishvili, A. Kwilinski, O. Sukhodolia, H. Dzwigol, D. Bobro, J. Kotowicz, Energies, 14(8), 2126 (2021)

69. Y. Kharazishvili, A. Kwilinski, H. Dzwigol, V. Liashenko, Virtual Economics, 4(2), 740 (2021)

70. O. Lyulyov, I. Vakulenko, T. Pimonenko, A. Kwilinski, H. Dzwigol, M. DzwigolBarosz, Energies, 14(12), 3497 (2021)

71. H. Dzwigol, M. Dźwigoł-Barosz, Financial and Credit Activity: Problems of Theory and Practice, 2(25), 424-437 (2018)

72. O. Arefieva, O. Polous, S. Arefiev, V. Tytykalo, A. Kwilinski, IOP Conference Series: Earth and Environmental Science, 628, 012039 (2021)

73. V. Boiko, A. Kwilinski, M. Misiuk, L. Boiko, Economic Annals-XXI, 175(1-2), 68-72 (2019)

74. S. Bogachov, A. Kwilinski, B. Miethlich, V. Bartosova, A. Gurnak, Entrepreneurship and Sustainability Issues, 8(2), 487-499 (2020)

75. O. Chygryn, Y. Bilan, A. Kwilinski, Marketing and Management of Innovations, 3, 356-368 (2020)

76. N. Dalevska, V. Khobta, A. Kwilinski, S. Kravchenko, Entrepreneurship and Sustainability Issues, 6(4), 1839-1860 (2019)

77. V.V. Dementyev, A. Kwilinski, Journal of Institutional Studies, 12(1), 100-116 (2020) 
78. V. Khrapkina, A. Kwilinski, J. Polcyn, K. Pająk, V. Stratonov, V. Kobets, V. Virtual Economics, 4(2), 41-73 (2021)

79. V. Koibichuk, N. Ostrovska, F. Kashiyeva, A. Kwilinski, Marketing and Management of Innovations, 1, 253-265 (2021)

80. V. Kondratenko, O. Okopnyk, L. Ziganto, A. Kwilinski, Marketing and Management of Innovations, 1, 87-94 (2020)

81. A. Kuzior, A. Kwilinski, V. Tkachenko, V. Entrepreneurship and Sustainability, 7(2), 1353-1376 (2019)

82. A. Kuzior, A. Kwilinski, I. Hroznyi, Energies, 14(9), 2572 (2021)

83. A. Kuzior, O. Lyulyov, T. Pimonenko, A. Kwilinski, D. Krawczyk, Sustainability, 13(15), 8145 (2021)

84. A. Kwilinski, Virtual Economics, 1(1), 7-25 (2018)

85. A. Kwilinski, Marketing and Management of Innovations, 4, 116-128 (2018)

86. A. Kwilinski, Academy of Accounting and Financial Studies Journal, 23(SI2), 1-6 (2019)

87. A. Kwilinski, V. Tkachenko, A. Kuzior, Journal of Security and Sustainability Issues, 9(2), 561-570 (2019)

88. A. Kwilinski, N. Dalevska, S. Kravchenko, I. Hroznyi, I. Kovalenko, Journal of Entrepreneurship Education, 22(SI1), 1-7 (2019)

89. A. Kwilinski, I. Ruzhytskyi, V. Patlachuk, O. Patlachuk, B. Kaminska, Journal of Legal, Ethical and Regulatory Issues, 22(SI2), 1-6 (2019)

90. A. Kwilinski, R. Volynets, I. Berdnik, M. Holovko, P. Berzin, P. Journal of Legal, Ethical and Regulatory Issues, 22(SI2), 1-6 (2019)

91. A. Kwilinski, K. Pajak, O. Halachenko, S. Vasylchak, Y. Pushak, P. Kuzior, Marketing and Management of Innovations, 4, 172-181 (2019)

92. A. Kwilinski, A. Kuzior, Management Systems in Production Engineering, 28(2), 119$123(2020)$

93. A. Kwilinski, Y. Zaloznova, N. Trushkina, N. Rynkevych, E3S Web of Conferences, 168, $00031(2020)$

94. A. Kwilinski, M. Dielini, O. Mazuryk, V. Filippov, V. Kitseliuk, Journal of Security and Sustainability Issues, 10(1), 345-358 (2020)

95. A. Kwilinski, D. Shteingauz, V. Maslov, Financial and Credit Activities: Problems of Theory and Practice, 3(34), 133-140 (2020)

96. A. Kwilinski, I. Slatvitskaya, T. Dugar, L. Khodakivska, B. Derevyanko, International Journal of Entrepreneurship, 24(1 Special Issue), 1-8 (2020)

97. A. Kwilinski, V. Litvin, E. Kamchatova, J. Polusmiak, D. Mironova, International Journal of Entrepreneurship, 25(1), 1-8 (2021)

98. Y. Kyrylov, V. Hranovska, V. Boiko, A. Kwilinski, L. Boiko, L. Journal of Risk and Financial Management, 13(12), 303 (2020)

99. V. Lakhno, V. Malyukov, T. Bochulia, Z. Hipters, A. Kwilinski, O. Tomashevska, International Journal of Civil Engineering and Technology, 9(8), 1802-1812 (2018)

100.O. Lyulyov, T. Pimonenko, A. Kwilinski, Y. Us, E3S Web of Conferences, 250, 03006 (2021)

101.K. Pająk, B. Kamińska, O. Kvilinskyi, O. Financial and Credit Activity: Problems of Theory and Practice, 2(21), 204-217 (2016) 
102.T. Savchenko, N. Basiurkina, O. Rodina, A. Kwilinski, Management Theory and Studies for Rural Business and Infrastructure Development, 41(1), 43-61 (2019)

103.V. Tkachenko, A. Kwilinski, O. Korystin, N. Svyrydiuk, I. Tkachenko, Journal of Security and Sustainability, 8(3), 375-385 (2019)

104.V. Tkachenko, A. Kwilinski, M. Klymchuk, I. Tkachenko, Management Systems in Production Engineering, 27(2), 119-123 (2019)

105.V. Tkachenko, A. Kwilinski, I. Tkachenko, P. Puzyrova, Marketing and Management of Innovations, 2, 228-238 (2019)

106.V. Tkachenko, A. Kwilinski, B. Kaminska, I. Tkachenko, P. Puzyrova, Financial and Credit Activity: Problems of Theory and Practice, 3(30), 85-94 (2019)

107.V. Tkachenko, A. Kuzior, A. Kwilinski, Journal of Entrepreneurship Education, 22(6), 1-10 (2019)

108.J. Polcyn, Management, 22(2), 171-186 (2018)

109.J. Polcyn, Sustainability, 13(15), 6846 (2021)

110.R. Abazov, Herald of Journalism, 58(4), 34-43 (2021)

111.A. Barrett, A. Bergin, D. Duffy, Economic \& Social Review, 37(1), 1-26 (2006). URL: http://hdl.handle.net/2262/59972

112.S. Morano-Foadi, International Migration, 43, 133-162 (2005). URL:https://doi.org/10.1111/j.1468-2435.2005.00344.x

113.D. Kancs, EERI Research Paper Series, 1, (2006). https://doi.org/10.1016/j.apgeog.2010.04.003

114.I. Turok, Regional Studies, 38, 1061-1075 (2004). https://doi.org/10.1080/0034340042000292647

115. U. Bronisz, W. Heijman, A. Miszczuk, Jahrb Regionalwiss 28, 133-143 (2008). https://doi.org/10.1007/s10037-008-0026-y

116. R. Huggins, Reg Stud, 37(1), 89-96 (2003). https://doi.org/10.1080/0034340022000033420

117.R. Huggins, I. Hiro, T. Piers, The Business and Economics Research Journal, 6(2), 155-172 (2013). URL: https://ssrn.com/abstract=2332832

118.R. Huggins, Regional Studies, 44(5), 639-658 (2010). dx.doi.org/10.1080/00343400802331312

119.R. Huggins, H. Izushi, Urban Studies, 50(5), 1030-1048 (2013). dx.doi.org/10.1177/0042098012458002

120.M. E. Porter, G. L. Clark, M. P. Feldman, M. S. Gertler (Eds.), The Oxford handbook of economic geography, 253-274 (2000).

121.M. Storper, The regional world: Territorial development in a global economy. New York, NY: The Guilford Press (1997)

122.U. Sadova, Ukrainian migration in the context of global and national challenges of the XXI century: a scientific publication. Lviv, 110 (2019). http://ird.gov.ua/irdp/p20190801.pdf

123.IOM "Migration in Ukraine: Facts and Figures" (2019). https://iom.org.ua/sites/default/files/iom-ukraine_facts-ukr_2019.pdf

124.Eurostat: Asylum and Managed Migration, URL:https://ec.europa.eu/eurostat/web/asylum-and-managedmigration/data/database 
125.P. Krugman, Growth on the periphery: Second wind for industrial regions? The Allander series. Glasgow, UK: Fraser Allander Institute (2003).

126. Website of the State Statistics Service of Ukraine. URL: http: //www.ukrstat.gov.ua

127.L. Kuriy, Regional economy, 4(62), 93-100 (2011). URL: http://re.gov.ua/re201104/re201104 093 KuriyLO.pdf

128.I. Berezhnyuk, Global Competitiveness Index. Customs Encyclopedia: in 2 volumes, 1, 472 (2013). ISBN 978-617-7094-09-7. URL:

https://web.archive.org/web/20190302204824/http://ir.nusta.edu.ua/jspui/bitstream/doc /456/1/414_IR.pdf

129. Socio-economic development of Ukraine for January-April 2019. State Statistics Service of Ukraine (2019) URL:

http://www.ukrstat.gov.ua/operativ/infografika/2019/soes/soes_04_2019.pdf

130. Volume of industrial products sold by region, State Statistics Service of Ukraine (2020).

URL:http://www.ukrstat.gov.ua/operativ/operativ2007/pr/orp/orp_u/arh_orp_u.html

131.S. Gromenkova, Scientific Bulletin of Kherson State University. Economic sciences, 29(1), 37-40 (2018). URL: http://nbuv.gov.ua/UJRN/Nvkhdu_en_2018_29(1)_9) 